\title{
Peningkatan Motivasi Belajar dan Kemampuan Berpikir Kritis Peserta Didik Menggunakan Model Think Pair Share Berbantuan Alat Peraga Bahan Bekas
}

\author{
Nurul Hidayah, Witri Anisa \\ Universitas Islam Negeri Raden Intan \\ nurulhidayah@radenintan.ac.id
}

\begin{abstract}
The purpose of this study is to improve students' motivation and critical thinking skills through think pair share model that is supported by used materials. Critical thinking ability is needed by students to be able to solve problems. To measure students' motivation, this study used questionnaires and to measure students' critical thinking skills, this study applied a test. The results show that from the average score of motivation, students' learning motivation reaches $59.8 \%$ in the first cycle of study and this proves that there is no significant improvement in students' motivation. Then, it increases up to 78,6 in the second cycle and $86.7 \%$ in the third cycle which means that students' motivation increases significantly. In relation to students' critical thinking skills, it is seen that there is a significant improvement in each skills, in which the average score of the test in cycle I is $54,2 \%$ and it increases up to $65,7 \%$ in cycle II and $83,8 \%$ in cycle III with the achievement score of $85 \%$. From these results it can be concluded that there is an increase in students' learning motivation and critical thinking skills through think pair share models supported with used material.
\end{abstract}

Keywords: Learning motivation, Critical thinking, learning model, think pair share, Used materials

Abstrak : Penelitian ini bertujuan untuk meningkatkan motivasi belajar dan kemampuan berpikir kritis peserta didik melalui model think pair share yang berbantuan bahan bekas. Berpikir kritis kemampuan yang dimiliki peserta didik agar mampu memecahkan permasalahan. Untuk mengukur motivasi menggunakan angket dan tes untuk mengukur kemampuan berpikir kritis peserta didik. Hasil penelitian dapat memperoleh hasil data yaitu pada rata-rata hasil motivasi belajar peserta didik mencapai rata-rata terlihat dari hasil motivasi belajar pada siklus I sebesar 59,8\%, yang belum mencapai keberhasilan motivasi belajar, kemudian dilanjutkan pada siklus ke II meningkat menjadi 78,6 dan pada siklus III meningkat menjadi 86,7\%, dan telah mencapai kriteria keberhasilan. Pada hasil tes kemampuan berpikir kritis mengalami peningkatan setiap siklus yaitu dengan nilai rata-rata pada siklus I $54,2 \%$, pada siklus II meningkat menjadi 65,7\% kemudian di siklus III

AR-RIAYAH : Jurnal Pendidikan Dasar vol. 3, no. 2, 2019

IAIN Curup - Bengkulu| pISSN2580-362X; eISSN2580-3611

http://journal.iaincurup.ac.id/index.php/JPD 
meningkat menjadi 83,8\% dengan indikator ketuntasan 85\%. Berdasarkan hasil penelitian tersebut maka dapat disimpulkan ada peningkatan motivasi belajar dan kemampuan berpikir kritis menggunakan model think pair share berbantuan alat peraga bahan bekas.

Kata Kunci: Motivasi belajar, berpikir kritis, Model Pembelajaran, think pair share dan bahan bekas.

\section{PENDAHULUAN}

Kegiatan belajar mengajar yang melahirkan interaksi unsur-unsur manusiawi adalah sebagai suatu proses dalam rangka mencapai tujuan pengajaran. motivasi adalah kekuatan, baik dari dalam maupun dari luar yang dapat mendorong seseorang untuk mendapatkan tujuan yang diharapkan. Motivasi dapat diartikan sebagai kekuatan seseorang yang dapat meningkatkan suatu prestasi dan antusiasnya dalam melaksanakan suatu tindakan.1

Kemampuan berpikir kritis adalah suatu kegiatan menganalisis ide kea rah yang lebih spesifik. Berpikir kritis merupakan suatu kemampuan seseorang untuk melakukan kesimpulan berdasarkan bukti-bukti.2 Pada dasarnya pelajaran IPA menekankan pendekatan kemampuan berpikir kritis dalam pembelajaran sehingga peserta didik mampu menemukan fakta-fakta dan sikap ilmiah yang berpengaruh dalam hasil pembelajaran.

Model think pair share memungkinkan peserta didik untuk bekerja sama dengan orang lain, mengoptimalkan keaktifan peserta didik dan memberikan kesempatan untuk bertanya, meringkas gagasan orang lain.3 Berdasarkan observasi untuk mengumpulkan data dengan melakukan tes soal dan pemberian angket di kelas IV MI Masyariqul Anwar 4 Sukabumi Bandar Lampung, masih kurangnya motivasi belajar dan kemampuan berpikir kritis peserta didik dalam belajar. Namun pada kenyataannya pendidik masih kesulitan untuk mengaktifkan peserta didik dalam belajar sehingga proses pembelajaran belum memenuhi standar proses pelajaran yang diharapkan.

Dengan adanya proses pembelajaran yang menarik peserta didik pasti akan lebih semangat dalam mengikuti pembelajaran yang berdampak positif pada motivasi belajar dan kemampuan berpikir kritis peserta didik. Maka berdasarkan permasalahan dan data di atas, peneliti memilih model think pair share berbantuan alat peraga bahan bekas yang diharapkan dapat membantu

1 Kompri. 2016. Motivasi pembelajaran perspektif guru dan siswa. Bandung: PT Remaja Rosda karya.

2 Yudi Budianti. 2018. Meningkatkan Kemampuan Berpikir Kritis Dengan menggunakan Model Cooperative Tipe Group Investigation Pada Siswa Kelas V Sd Negeri Harapan Jaya 1 Bekasi Utara. Pedagogik Vol. VI, No.1.

3 Aris Shoimin. 2013. 68 Model Pembelajaran Inovatif Dan Kurikulum 2013. Yogyakarta: Ar- Ruzz Media. 
peserta didik meningkatkan motivasi belajar dan kemampuan berpikir kritis peserta didik.

\section{LANDASAN TEORI}

\section{Model Pembelajaran Think Pair Share}

Model pelajaran Think Pair Share merupan model pembelajaran yang sederhana, namun sangat bermanfaat dalam proses pembelajaran. Model ini membuat peserta didik untuk saling membantu, model ini biasanya dikenal dengan waktu berpikir yang menjadi faktor kuat untuk peserta didik aktif dalam merspon pertanyaan teman maupun aktif bertanya.4 Model pembelajaran think pair share terdiri dari tiga tahapan thinking (berpikir), pembelajaran diawali oleh pendidik membuat pertanyaan atau suatu permasalahan agar peserta didik berpikir. Selanjutnya pairing (berpasangan) pendidik membagi peserta didik untuk membuat kelompok kecil yaitu 2 orang, setelah itu memberikan waktu sebentar untuk diskusikan. Kemudian tahap ketiga sharing (berbagi) tahap ini bertujuan untuk perwakilan kelompok membagikan hasil diskusinya, dan membuka sesi tanya jawab.

Penggunaan model think pair share mempunyai pengaruh sangat besar terhadap belajar. Adapun manfaat sebagai berikut:

a. Membuat peserta didik untuk bekerja sendiri dan saling membatu temannya. Peserta didik harus saling membatu untuk menemukan suatu permasalahan yang diberikan saat pembelajaran.

b. Mengoptimalkan keikutan serta peserta didik, agar semangat dan termotivasi dalam kegiatan diskusi.

c. Memberikan kesempatan peserta didik untuk menunjukan kemampuan berpikir kritis yang biasanya dibutuhkan dalam model ini adalah berbagi informasi, bertanya, menganalisis pertanyaaan orang lain.5

\section{Motivasi Belajar}

Motivasi menurut Mc. Donald dalam buku djamarah yang mengatakan bahwa motivasi adalah suatu perkembangan energi didalam diri seseorang yang ditandai timbulnya perasaan untuk mencapai tujuan. Oleh karena itu seseorang memiliki tujuan maka seseorang memiliki motivasi yang kuat untuk mencapainya dengan segala upaya yang dapat dilakukan. Motivasi belajar

4 Ibid, 208

5 Miftahul Huda. 2017. Model-Model Pengajaran dan Pembelajaran. Yogyakarta: Pustaka Pelajar. Hlm. 206 
merupakan segi kejiwaan yang mengalami perkembangan artinya terpengaruh oleh kondisi fisiologis dan kematangan psikologis peserta didik. 6

Motivasi memiliki peran yang strategis dalam aktifitas belajar seseorang. Beberapa prinsip motivasi belajar yaitu:

a. Motivasi sebagai pendorong untuk melakukan kegiatan belajar agar lebih semangat dalam aktivitas belajar.

b. Motivasi berupa pujian lebih baik dari pada hukuman, karena dengan memberikan hukuman peserta didik melakukan kegiatan pelajaran dikarenakan menghindari dari hukuman.

c. Motivasi melahirkan prestasi dalam belajar karena dengan termotivasi belajar peserta didik akan giat mengerjakan pelajaran di rumah dan di sekolah sehingga tercapailah harapan hasil belajar yang memuaskan. 7 . Berikut indikator motivasi belajar sebagai berikut:

1) Adanya hasrat dan keinginan belajar

2) Adanya dorongan dan kebutuhan dalam belajar

3) Adanya harapan dan cita-cita dimasa depan

4) Adanya harapan dalam mengikuti pelajaran

5) Menimbulkan adanya kegiatan yang menarik dalam belajar

6) Adanya lingkungan belajar yang kondusif, sehingga dapat memungkinkan seorang peserta didik dapat belajar.

\section{Kemampuan Berpikir Kritis}

Berpikir adalah merupakan sebuah aktivitas yang selalu dilakukanmanusia, bahkan ketika sedang tidur. Berpikir menurut Santrock menj elaskan pemikiran kritis adalah adalah pemikiran refleksi dan produktif yang melibatkan hasil bukti.8 Kemampuan berpikir kritis dapat digunakan untuk memperoleh informasi baru bagi siapapun, terutama dengan peserta didik yang membutuhkan informasi baru dalam pengetahuan.9. Kebanyakan sebagian orang memandang kata kritis merupakan kritik, yang orang berpandangan bahwa berpikir kritis hanya untuk mencari kesalahan dan kelemahan orang lain untuk menujukan kehebatannya maupun mencari keuntungan.

Indikator berpikir kritis dapat diklasifikasi sebagai berikut

\footnotetext{
6 Kompri. 2016. Motivasi pembelajaran perspektif guru dan siswa. Bandung: PT Remaja Rosda karya, hlm. 229

7 Hamzah B. Uno. 2013. Teori Motivasi Dan Pengukurannya. Jakarta: Bumi Aksara, hlm. 23

8 Desmita. 2014. Psikologi Pengembangan Peserta Didik. Bandung: PT Remaja Rosdakarya, hlm 153

9 Siti Anisatun Nafi'ah. 2018. Model-Model Pembelajaran Babasa Indonesia di SD/MI, Yogyakarta, Ar-Ruzz Media, hlm 141
} 
a. Memberikan penjelasan sederhana yang terdiri atas pertanyaan, menganalisis pendapat serta membuka suatu kegiatan bertanya dan menjawab.

b. Membangun keterampilan dasar, yang menjelaskan hasi suatu gagasan dengan adanya sumber observasi dan mempertimbangkan hasilnya.

c. Menyimpulkan yang terdiri atas: membuat deduksi dan mempertimbangkan hasil pembelajaran, mempertimbangkan hasil induksi, membuat dan mempertimbangkan nilai keputusan.

d. Membuat penjelasan lebih lanjut yang terdiri atas mengidentifikasi pemahaman.

e. Membuat strategi dan taktik, yang terdiri atas membuat suatu tindakan

Kemampuan berpikir kritis membuat kita tidak hanya menganggap suatu masalah dari satu sisi saja, melainkan dari sisi yang lain, dikarenakan dalam kemampuan berpikir kritis disertai dengan pemahaman konsep dan fakta-fakta yang ada serta analisis yang memperkuat argumen yang diberikan.10

\section{Alat Peraga Berbahan Bekas}

Dalam berbagai proses pembelajaran di Indonesia, peranan pendidik masih sangat dominan walaupun sebagian dari pendidik telah berupaya menjadi fasilitator disamping sebagai sumber informasi. Namun kenyataannya kemampuan manusia sangat terbatas sehingga perlu bantuan dalam menjelaskan setiap pemaparan materi khususnya pada materi IPA. Manfaat alat peraga bahan bekas peserta didik dengan mudahnya menangkap memahami materi yang disampaika, karena dapat menyampaikan suatu yang abstak menjadi nyata. Sehingga waktu yang tertata dan tidak terlalu mengeluarkan tenaga meningkatkan peran tenaga pendidik lebih positif.

Dengan alat peraga bahan bekas peserta didik dapat memperagakan secara langsung terkait materi yang diajarkan sesuai dengan konsep yang diajarkan dan biaya yang terjangkau. pembelajaran menggunakan alat peraga dapat mengoptimalkan fungsi seluruh panca indra dari melihat, mendengar, meraba dan menggunakan pikiran secara logis.

10 Yudi Budianti. 2018. Meningkatkan Kemampuan Berpikir Kritis Dengan menggunakan Model Cooperative Tipe Group Investigation Pada Siswa Kelas V Sd Negeri Harapan Jaya 1 Bekasi Utara. Pedagogik Vol. VI, No.1. hlm 01 

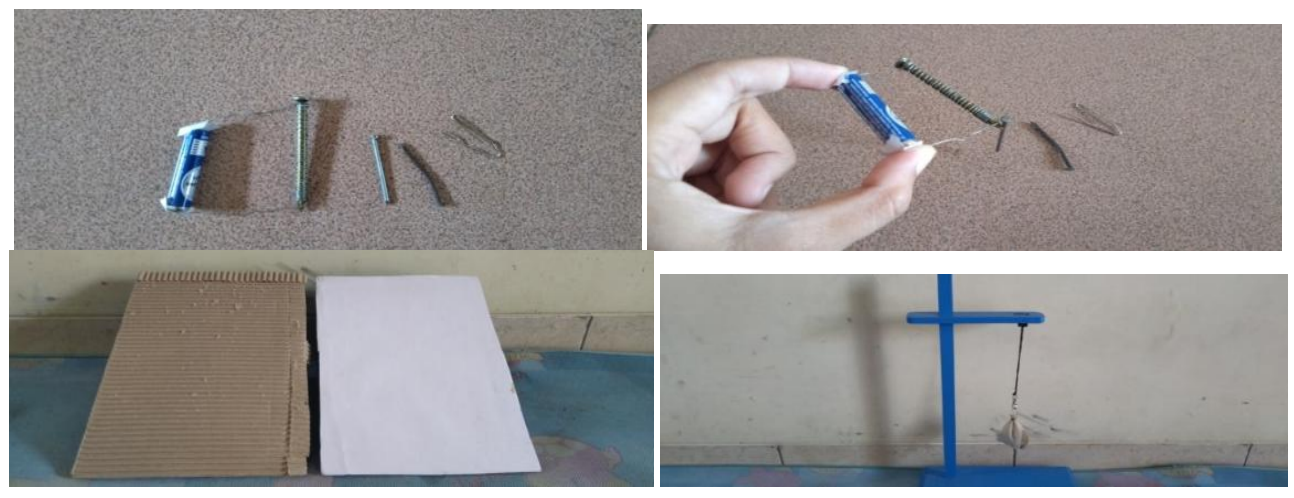

Gambar 1. Alat Peraga Berbahan Bekas" Gaya Dan Gerak"

\section{METODE PENELITIAN}

Penelitian tindakan sebagai proses investigasi tersusun dengan berulangulang yang bertujuan untuk mencari hasil dengan perbaikan terhadap sistem. Terdiri dari 4 tahap, yaitu: (1) perencanaan, (2) tindakan, (3) Observasi (4) Refleksi.

Subjek penelitian adalah kelas IV B MI Masyariqul Anwar (MIMA) 4 Sukabumi Bandar Lampung. Objek penelitiannya peningkatan motivasi belajar dan kemampuan berpikir kritis peserta didik menggunakan model think pair share berbantuan alat peraga bahan bekas.

\section{Teknik Pengumpulan Data}

Untuk mendapatkan data dan informasi yang dilaksanakan peneliti dalam penelitian ini, maka peneliti menggunakan beberapa cara antara lain sebagai berikut;

a. Observasi

Pengamatan atau observasi adalah kegiatan pengamatan (pengambilan data) untuk memotret seberapa jauh efek tindakan sudah mencapai tujuan yang diinginkan di dalam kegiatan observasi ini, peneliti mengamati secara langsung peserta didik pada saat kegiatan pembelajaran IPA di kelas.

b. Wawancara

Peneliti menggunakan wawancara terbuka, yaitu interview melalui tatap muka secara langsung dengan mewawancarai wali kelas IV B MIMA 4 Sukabumi Bandar Lampung.

c. Tes

Penggunaan tes dalam penelitian ini bertujuan untuk mengetahui kemampuan berpikir kritis peserta didik kelas IV B dalam penelitian ini, peneliti melakukan tes tertulis yaitu pemberian butir-butir soal esay 
kepada peserta didik untuk mengetahui sejauh mana kemampuan mereka dalam memahami mata pelajaran IPA.

d. Dokumentasi

Peneliti melakukan pengumpulan data berupa dokumentasi dengan mendokumentasikan kegiatan pembelajaran di kelas IV B MIMA 4 Sukabumi Bandar Lampung.

\section{Instrumen Penelitian}

a. Observasi

Observasi awal adalah cara untuk mengetahui gambaran situasi yang ada pada kegiatan pembelajaran di dalam kelas. Teknik pengumpulan data dengan observasi digunakan bila berkenaan dengan perilaku manusia, proses kerja, gejala-gejala alam dan bila responden tidak terlalu banyak.11

Tabel 1 Kisi-Kisi Penilaian Observasi Peserta Didik

\begin{tabular}{ccccc}
\hline No & Hal yang diamati & \multicolumn{3}{c}{ Skor } \\
\hline Peserta didik & 1 & 2 & 3 & 4 \\
\hline
\end{tabular}

1. Keaktifan peserta didik:

a. Peserta didik aktif mengikuti materi yang disampaikan.

2. Perhatian peserta didik:

a. Fokus pada materi yang disampaikan

3. Kedisiplinan:

a. Kehadiran absen

b. Datang tepat waktu

4. Penugasan:

a. Mengerjakan tugas yang diberikan

b. Tes Tertulis

Penggunaan tes tertulis dapat dilakukann dengan cara memberikan soal yang akan dikerjakan oleh peserta didik setelah kegiatan diakhir siklus. Setelah itu, peneliti akan melihat jumlah rata-rata nilai yang diperoleh peserta didik diakhir siklus.

11 Sugiyono. 2018. Metode Penelitian Kuantitatif, Kualitatif,dan R\&D. Bandung: Alfabeta. hlm 137 
Tabel 2. Kisi-Kisi Soal

\begin{tabular}{|c|c|c|c|}
\hline No & Kopetensi Dasar & Indikator Soal & $\begin{array}{l}\text { No } \\
\text { soal }\end{array}$ \\
\hline \multirow[t]{3}{*}{1.} & $\begin{array}{l}\text { Memahami macam-macam } \\
\text { gaya antara lain gaya otot, gaya } \\
\text { listrik, gaya mahnet, gaya } \\
\text { gravitasi, dan gaya gerak. }\end{array}$ & $\begin{array}{l}\text { Menjelaskan pengertian } \\
\text { gaya }\end{array}$ & $1,4,5$ \\
\hline & & $\begin{array}{l}\text { Menerangkan macam- } \\
\text { macam gaya }\end{array}$ & 2 \\
\hline & & $\begin{array}{l}\text { Mencontohkan macam- } \\
\text { macam gaya yang terjadi } \\
\text { di kehidupan sehari-hari }\end{array}$ & 3,9 \\
\hline \multirow[t]{3}{*}{2.} & $\begin{array}{l}\text { Memahami hubungan antara } \\
\text { gaya dan gerak }\end{array}$ & $\begin{array}{l}\text { Menjelaskan dari gaya } \\
\text { gesek }\end{array}$ & 8 \\
\hline & & $\begin{array}{l}\text { Menunjukan } \text { bahawa } \\
\text { gaya dapat merubah } \\
\text { bentuk benda }\end{array}$ & 11 \\
\hline & & $\begin{array}{l}\text { Mengklarifikasi gaya } \\
\text { yang terjadi pada suatu } \\
\text { kejadian. }\end{array}$ & $6,7,10$ \\
\hline
\end{tabular}

\section{Jenis Data Yang Digunakan}

Dalam menganalisa data yang bersifat kuantitatif adalah data yang dapat diolah dengan pengitungan-pengitungan. (Sugiono, 2018 : 7 ). Menggunakan tehnik analisis deskriptif kuantitatif atau statistik yakni penghitungaan yang digunakan untuk pengecekan data yang telah terkumpul.

a. Analisis data observasi dan angket motivasi belajar

$$
N p=\frac{r}{S m} \times 100 \%
$$

$\mathrm{Np}=$ nilai persen yang dicari

$\mathrm{r}=$ skor mentah yang diperoleh siswa

$\mathrm{Sm}=$ skor maksimum 


\section{Tabel 3 : Kriteria Hasil Presentase Skor Motivasi Peserta Didik}

\section{Presentase Yang Diperoleh Keterangan}

\begin{tabular}{cc}
\hline $85 \%-100 \%$ & Sangat tinggi \\
\hline $70 \%-85 \%$ & Tinggi \\
\hline $55 \%-70 \%$ & Sedang \\
\hline $40 \%-55 \%$ & Rendah \\
\hline $0 \%-40 \%$ & Sangat rendah \\
\hline
\end{tabular}

b. Analisis tes

Analisis tes merupakan alat ukur peserta didik tingkat penguasaan dan pemahaman materi pembelajaran tingkat berpikir kritis peserta didik pada materi yang sudah diajarkan (Sochibin, 2013:81).

Nilai $=\frac{\text { skor yang diperoleh siswa }}{\text { skor maksimal }} \times 100$

Tabel 4 : Kriteria Penilaian Kemampuan Berpikir Kritis Siswa

\begin{tabular}{cc}
\hline Skala perolehan & Kategori \\
\hline $81,25<\mathrm{x} \leq 100$ & Sangat kritis \\
\hline $62,50<\mathrm{x} \leq 81,25$ & Kritis \\
\hline $43,75<\mathrm{x} \leq 62,50$ & Kurang \\
\hline $25,00<\mathrm{x} \leq 43,73$ & Sangat kurang \\
\hline
\end{tabular}

\section{HASIL PENELITIAN}

\section{Deskripsi Data}

Perencanaan pada penelitian ini peneliti menggunakan penelitian PTK atau penetitian tindakan kelas dengan menggunakan siklus dimana setiap siklusnya menggambarkan peningkatan dari setiap peserta didik. Pada setiap siklus terdiri dari $3 \mathrm{x}$ pertemuan dipertemuan terakhir peneliti memberikan tes soal dan angket motivasi belajar. pada siklus ini peneliti menerapkan model TPS. sebelum memulai pelajaran peneliti menyiapkan rencana pelaksanaan pelajaran, materi, alat peraga dan menyiapkan lembar observasi.

Pelaksanaan dan observasi tindakan dilakukan di kelas IV dan dilakukan sesui perencaan yang telah disusun. pada siklus ini dilaksanakan tiga kali pertemuan. pada siklus ini terlihat peserta didik belum memahami model yang diterapkan, peserta didik masih belum berani mengeluarkan pendapatnya maupun bertanya. dari hasil siklus I menunjukan motivasi belajar dan berpikir kritis peserta didik masih rendah. Hasil tes berpikir kritis peserta didik pada mata pelajaran IPA dengan rata-rata nilai $54,2 \%$ pada siklus I.

Hasil angket diperoleh motivasi belajar peserta didik pada mata pelajaran IPA sebesar 59,8\% dalam kategori rendah. dari hasil tersebut maka 
dilakukan lagi dengan siklus dua dengan tapah yang sama disiklus sebelumnya. perencanaan dengan menyiapkan materi, alat peraga, rencana pelaksanaan pelajaran dan lembar ovservasi. pada pelajaran ini peserta didik sudah banyak memahami model yang diterapkan, adanya peserta didik yang berani bertanya saat berdiskusi dan antusis peserta didik yang ingin mencoba meragakan salah satu media didepan kelas.

Hasil tes berpikir kritis peserta didik pada mata pelajaran IPA dengan rata-rata nilai $64,7 \%$ pada siklus II, dengan ketuntasan presentase $40 \%$. Yang dimana hanya 8 peserta didik yang memiliki berpikir kritis tinggi, sedangkan 12 peserta didik masih dalam kategori kurang. Namun peserta didik mengalami peningkatan dari siklus sebelumnya.

Hasil angket diperoleh motivasi belajar peserta didik sebesar 78,6\% dalam kategori tinggi namun masih belum mencapai keberhasilan. Dari uraian di atas hasil pembelajaran belum maksimal maka dilakukan rencan perbaikan, karena masih banyak peserta didik yang belum mencapai kriteria ketuntasan sehingga dilakukan perencanaan pada tindakan selanjutnya.

Selanjutnya pelaksanaan siklus III sama halnya dengan siklus I dan II, tindakan siklus III ini dilaksanakan tiga kali pertemuan dengan pertemuan ketiga diberikan tes soal untuk mengukur berpikir kritis dan juga angket motivasi belajar peserta didik. Hasil tes berpikir kritis peserta didik pada mata pelajaran IPA dengan rata-rata nilai $83,8 \%$ pada siklus III, dengan ketuntasan presentase $85 \%$. Berdasarkan hasil dari perolehan nilai rata-rata pada siklus III tersebut berpikir kritis peserta didik sebesar 83,8\%, maka nilai rata-rata tersebut sudah mencapai indikator keberhasilan yang ditetapkan yaitu 85. Kegiatan pembelajaran pada Siklus III berlangsung lebih efektif dan efisien peserta didik dan pendidik terlibat aktif dalam proses pembelajaran di dalam kelas.

Hasil angket diperoleh motivasi belajar peserta didik pada mata pelajaran IPA menggunakan model think pair share berbantu alat peraga bahan bekas sebesar 86,7\% dalam kategori tinggi. Sedangkan dalam peningkatan Dengan data ketuntansan $85 \%$ yang mencapai indikator keberhasilan. Tahapan pada penelitian ini adalan perencanaan, pelalsanaaan observasi dan refleksi. Pada Siklus 1 perolehan rata-rata nilai motivasi belajar yaitu 59,8\% dengan kriteria sedang, nilai rata-rata berpikir kritis peserta didik 54,2\%. Pada hasil Siklus II perolehan rata-rata nilai 78,6\% dengan kategori tinggi namun belum memenuhi indikator keberhasilan. Untuk berpikir kritis peserta didik dengan nilai rata-rata $64,7 \%$. Pada siklus III perolehan rata-rata $86,7 \%$ dengan kriteria tinggi. Untuk berpikir kritis peserta didik meningkat menjadi 83,8\%. Dari hasil ini dapat dilihat Peserta didik sudah ada peningkatan-peningkatan baik dari hasil peserta didik. Pada perolehan nilai rata-rata motivasi belajar dan berpikir kritis peserta didik di kelas IV B yang sudah mencapai indikator keberhasilan yang ditetapkan. Maka dapat disimpulkan bahwa penelitian dinyatakan berhasil dengan melakukan penerapan model pembelajaran think pair share berbantuan alat peraga bahan bekas. 


\section{PEMBAHASAN}

Pada penelitian yang sudah dilaksanakan pada siklus I,II,dan III dengan model think pair share berbantuan alat peraga bahan bekas maka peneliti memperoleh hasil sebagai berikut :

\section{a. Hasil Motivasi Belajar}

\section{Tabel 11 : Hasil Rata-Rata Angket Motivasi Belajar Peserta Didik Siklus I-III}

\begin{tabular}{ccc}
\hline Siklus & Rata-rata & Kriteria \\
\hline I & $59,8 \%$ & Sedang \\
\hline II & $78,6 \%$ & Tinggi \\
\hline III & $86,7 \%$ & Tinggi \\
\hline
\end{tabular}

Dari tabel di atas maka terlihat perubahan nilai rata-rata motivasi belajar peserta didik berdasarkan angket motivasi belajar selama siklus I-III.

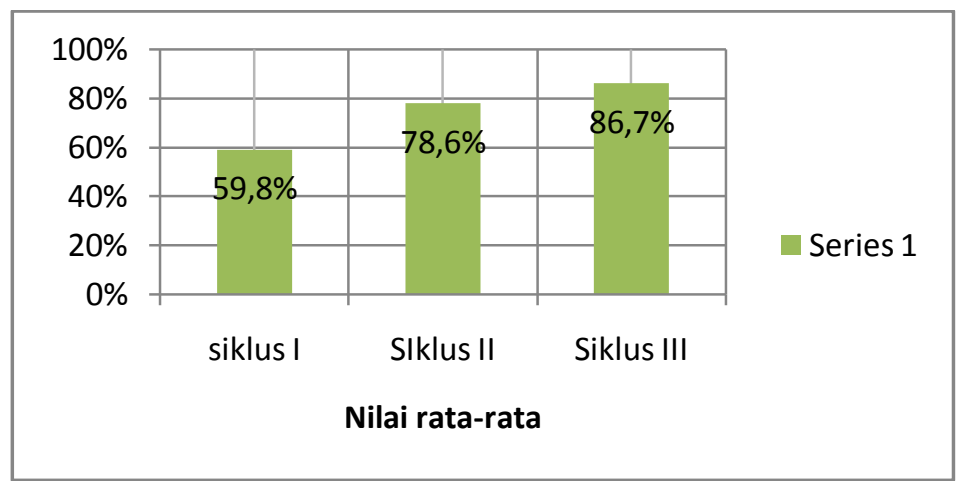

\section{Gambar 1 : Grafik Hasil Rata-Rata Angket Motivasi Belajar}

Berdasarkan tabel di atas dapat diketahui bahwa motivasi belajar peserta didik pada pelajaran IPA peserta didik kelas IV B MIMA 4 Sukabumi berdasarkan hasil penyebaran angket motivasi belajar pada siklus I 59,8\% dan pada siklus II meningkat menjadi 78,6\% kemudian pada siklus ke III meningkat menjadi $86,7 \%$.

a. Hasil Kemampuan Berpikir Kritis Peserta Didik

Berdasarkan perolehan hasil dari tes soal untuk mengukur berpikir kritis peserta didik dapat terlihat rata-rata peningkatan peserta didik. berikut data grafik berpikir kritis peserta didik pada siklus I-III. 


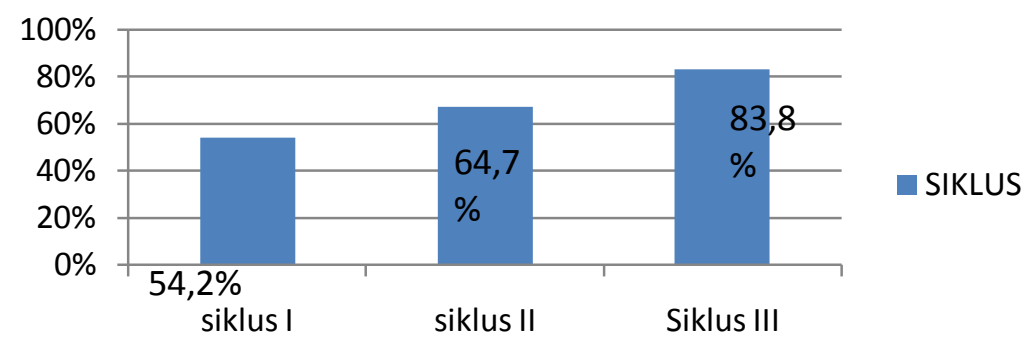

\section{Gambar 2 : Grafik Hasil Tes Berpikir Kritis Peserta Didik}

Hasil tes untuk kemampuan berpikir kritis peserta didik dengan menggunakan model think pair share berbantuan alat peraga bahan bekas meningkat, hal ini dapat dilihat dari hasil tes dengan nilai rata-rata pada siklus I $54,2 \%$ meningkat menjadi $65,7 \%$ kemudian di siklus III meningkat menjadi $83,8 \%$ dengan indikator ketuntasan $85 \%$.

\section{KESIMPULAN}

Berdasarkan hasil penelitian dan pembahasan peningkatan motivasi belajar dan berpikir kritis peserta didik menggunakan model think pair share berbantuan alat perega bahan bekas dapat diambil kesimpulan bahwa model think pair share berbantu alat peraga bahan bekas dapat meningkatkan motivasi belajar dan kemampuan berpikir kritis peserta didik. Hal ini dapat dilihat dari hasil setiap siklusnya. Terlihat dari hasil motivasi belajar pada siklus I sebesar 59,8\% meningkat menjadi 78,6 pada siklus ke II, dan meningkat menjadi 86,7\% Pada siklus III. Sedangkan pada hasil tes kemampuan berpikir kritis belajar peserta didik mengalami peningkatan yaitu dengan nilai rata-rata pada siklus I $54,2 \%$ meningkat menjadi $65,7 \%$ kemudian di siklus III meningkat menjadi $83,8 \%$ dengan indikator ketuntasan $85 \%$.

\section{DAFTAR PUSTAKA}

Alfianti Naimah. 2017. Penerapan Model Kooperatif Tipe Think Pair Share Dalam Peningkatan Hasil Belajar Ipa Kelas V Sd, Volume 1, Nomer 1. Issn 2549998x.

Aris Shoimin. 2013. 68 Model Pembelajaran Inovatif Dan Kurikulum 2013. Yogyakarta: Ar- Ruzz Media.

Desmita. 2014. Psikologi Pengembangan Peserta Didik. Bandung: PT Remaja Rosdakarya. 
Erika Puspita, Punaji Setyosari, Amirudin. 2016. Peningkatan Motivasi dan Hasil Belajar Melalui Think Pair Share di sekolah Dasar. Teori Pendidikan dan Pengembangan. Volume: 1 Nomer 7.

Hamzah B. Uno. 2013. Teori Motivasi Dan Pengukurannya. Jakarta: Bumi Aksara.

Kompri. 2016. Motivasi pembelajaran perspektif guru dan siswa. Bandung: PT Remaja Rosda karya.

Kisyani-Laksono, Tatag Yuli Eko Siswanto. 2018. Penelitian Tindakan Kelas. Bandung: Remaja Rosdakarya.

Kunandar. 2016. Langkah Mudah Penelitian Tindakan Kelas Sebagai Pengembangan Profesi Guru. Jakarta: Rajawali.

Miftahul Huda. 2017. Model-Model Pengajaran dan Pembelajaran. Yogyakarta: Pustaka Pelajar

Riduwan. 2016. Dasar-Dasar Statistika. Bandung: Alfabeta.

Sardiman. 2016. Interaks dan Motivasi Belajar Mengajar. Jakarta: Raja Grafindo.

Siti Anisatun Nafi'ah. 2018. Model-Model Pembelajaran Babasa Indonesia Di Sd/Mi, Yogyakarta, Ar-Ruzz Media.

Sochibin, Dwijananti. 2013. Penerapan Model Pembelajaran Inkuiri Terpimpin Untuk Meningkatkan Pemahaman Dan Berpikir Kritis Siswa SD, Jurnal Pendidikan Fisika Indonesia 5. 2013, Issn: 1693-1246.

Sri Purwati. 2015. Meningkatkan Kemampuan Komunikasi Dan Berpikir Kritis Matamatis Siswa Seklah Dasar Dengan Model Missouri Mathematics Project (Mmp),Terampil, Jurnal Pendidikan Pembelajaran Dasar. Volume 2 Nomer 2. P-Issn 2355-1925.

Sugiyono. 2018. Metode Penelitian Kuantitatif, Kualitatif,dan R\&D. Bandung: Alfabeta.

Tasiwan, Nugroho, Hartono. 2014. Analisis Tingkat Motivasi Siswa Dalam Pembelajaran IPA Model Advance Organizer Berbasis Proyek, Jurnal Pendidikan IPA Indonesia, Jpii 3 (1). . 
178 | AR-RIAYAH : Jurnal Pendidikan Dasar vol. 3, no. 2, 2019

Yudi Budianti. 2018. Meningkatkan Kemampuan Berpikir Kritis Dengan menggunakan Model Cooperative Tipe Group Investigation Pada Siswa Kelas V Sd Negeri Harapan Jaya 1 Bekasi Utara. Pedagogik Vol. VI, No.1. 